\title{
Penerapan Proses Redistribusi antar Jaringan IPv6 Menggunakan Protokol Routing OSPF dan IS-IS
}

\section{Implementing of the Redistribution Process Between IPv6 Networks Using OSPF and IS-IS Routing Protocols}

\author{
Kukuh Nugroho, ${ }^{1, *}$, Adlina ${ }^{2}$ \\ 1,2 Program Studi S1 Teknik Telekomunikasi, \\ Fakultas Teknik Telekomunikasi dan Elektro, Insitut Teknologi Telkom Purwokerto \\ Jl. DI Panjaitan no 128 Purwokerto, Jawa Tengah, Indonesia \\ 1,*Penulis Korespondensi: kukuh@ittelkom-pwt.ac.id
}

Received on 30-06-2020, accepted on 31-12-2020, published on 31-12-2020

\begin{abstract}
Abstrak
Jaringan memegang peranan penting agar data dapat dipertukarkan antar perangkat komputer. Proses komunikasi dapat terjadi antar dua atau lebih perangat komputer dalam jaringan. Proses komunikasi antar perangkat komputer tersebut dapat terjadi dalam jaringan yang sama atau berbeda. Selain jaringan, protokol yang digunakan untuk mengalamati perangkat juga memegang peranan penting agar data dapat dikirimkan ke perangkat tujuan. Meningkatnya jumlah perangkat yang terhubung dalam jaringan, khususnya Internet menyebabkan berkurangnya alokasi dari penggunaan protokol pengalamatan yang saat ini digunakan yaitu IP versi 4 . Sehingga perlu penggunaan protokol pengalamatan versi terbaru yaitu IP versi 6 (IPv6). Ketika proses komunikasi terjadi antar jaringan yang berbeda, maka diperlukan peran dari perangkat router. Proses routing akan dilakukan oleh perangkat tersebut agar data dapat dikirimkan ke tujuan. Proses routing akan mengalami permasalahan apabila proses tersebut terjadi antar wilayah jaringan yang menggunakan protokol routing yang berbeda. Proses redistribusi informasi rute antar wilayah yang berbeda penggunaan protokol routing diperlukan untuk mengatasi masalah ini. Pada penelitian ini digunakan jaringan uji yang menggunakan dua protokol routing yang berbeda yaitu OSPF versi 3 dan IS-IS yang mendukung penggunaan protokol pengalamatan IPv6. Proses pengujian menggunakan layanan transfer file dengan menggunakan protokol FTP (File Transfer Protocol) dengan beban trafik data sebesar 50 MByte. Hasil pengujian memperlihatkan bahwa nilai delay yang dihasilkan ketika data dikirimkan dari jaringan yang menerapkan protokol routing OSPFv3 ke IS-IS sebesar 35,128 ms. Sedangkan ketika data dikirimkan dari arah kebalikan yaitu dari jaringan yang menerapkan protokol routing IS-IS ke OSPFv3 menghasilkan nilai delay yang lebih besar yaitu sebesar $59,841 \mathrm{~ms}$.
\end{abstract}

Kata kunci: IPv6, IS-IS, OSPFv3, Redistribusi

\section{Abstract}

Networks play an important role so that data can be exchanged between computer devices. The communication process can occur between two or more computer devices in a network. The communication process between these computer devices can occur in the same or different networks. In addition to the network, the protocol used to address the device also plays an important role so that data can be sent to the destination device. The increasing number of devices connected to the network, especially the Internet, causes a reduction in the allocation of the currently used addressing protocol, namely IP version 4 . So it is necessary to use the latest version of the addressing protocol, namely IP version 6 (IPv6). When the communication process occurs between different networks, the role of the router is needed. The routing process will be carried out by the device so that data can be sent to the 
destination. The routing process will experience problems if the process occurs between network areas that use different routing protocols. The process of redistribution of route information between different regions using routing protocols is needed to overcome this problem. This research uses a test network that uses two different routing protocols, namely OSPF version 3 and IS-IS which supports the use of the IPv6 addressing protocol. The test process uses a file transfer service using the FTP (File Transfer Protocol) protocol with a data traffic load of $\mathbf{5 0}$ MByte. The test results show that the delay value generated when data is sent from a network that applies the OSPFv3 routing protocol to IS-IS is $\mathbf{3 5 . 1 2 8} \mathbf{m s}$. Meanwhile, when data is sent from the opposite direction, namely from a network that applies the IS-IS routing protocol to OSPFv3 it produces a greater delay value of $59.841 \mathrm{~ms}$.

Keywords: IPv6, IS-IS, OSPFv3, Redistribution

\section{Pendahuluan}

Perangkat komputer dapat saling terhubung dan mempertukaran data antar satu komputer ke komputer yang lain tidak terlepas dari peran sebuah jaringan. Jaringan dapat dibedakan berdasarkan wilayah atau cakupan-nya yaitu LAN (Local Area Network) dan WAN (Wide Area Network). Komputer yang terletak pada jaringan dengan skala yang lebih luas memerlukan bantuan perangkat penghubung yang dapat menghubungkan antar perangkat komputer pada wilayah jaringan yang berbeda. Perangkat penghubung tersebut adalah router. Konsep dalam menghubungkan antar wilayah jaringan yang berbeda dinamakan juga dengan istilah internetwork [1]. Perangkat router kalau dilihat dari basis konsep protokol TCP/IP terdapat pada layer network. Perangkat tersebut akan mengirimkan data antar wilayah jaringan yang berbeda segmen. Perangkat router akan menggunakan bantuan tabel routing yang berisi alamat tujuan dari paket, sehingga paket dapat dikirimkan ke perangkat tujuan.

Routing sendiri memiliki arti sebuah proses dalam meneruskan data dalam jaringan ke wilayah jaringan yang lain. Dengan proses tersebut paket bisa diteruskan ke perangkat tujuan oleh perangkat router. Jenis routing sendiri dibagi menjadi dua bagian; routing secara manual dan otomatis atau dinamakan juga dengan proses routing dinamis. Proses routing dinamis menerapkan konsep routing yang dapat mempelajari rute dari alamat network lawan secara otomatis dengan menggunakan bantuan protokol routing, seperti RIP (Routing Information Protocol), OSPF (Open Shortest Path First) atau IS-IS (Intermediate System to Intermediate System) [2]. Informasi rute lawan akan dikumpulan oleh protokol routing. Biasanya dalam sebuah jaringan hanya menggunakan satu protokol routing yang sama. Akan tetapi lebih banyak jaringan yang menggunakan beberapa protokol routing berbeda. Informasi rute hanya dipertukarkan dalam jaringan yang menerapkan protokol routing yang sama. Namun apabila proses pertukaran melibatkan protokol routing yang berbeda, diperlukan bantuan metode redistribusi. Proses Redistribusi sendiri merupakan metode yang digunakan oleh protokol routing dalam meneruskan informasi rute dari protokol routing yang satu ke protokol routing yang lain. Informasi rute dalam tabel routing akan dipertukarkan oleh masingmasing router. Karakteristik router yang diaktifkan metode redistribusi akan menggunakan konsep matrik dan proses pemilihan jalur untuk mengirim data yang berbeda antar router.

Internet merupakan jaringan yang menerapkan penggunaan protokol routing yang berbeda dan jumlah router yang banyak. Jaringan Internet memiliki skala yang sangat luas (dunia), dimana di dalam jaringan Internet terdapat ribuan atau lebih perangkat yang terhubung. Perangkat tersebut memerlukan protokol pengalamatan agar data bisa dipertukarkan antar perangkat. IP (Internet Protocol) adalah protokol pengalamatan yang umum digunakan. Namun dengan kapasitas IPv4 yaitu sebesar 32 bit akan habis digunakan dikarenakan jumlah perangkat yang harus dihubungan ke jaringan Internet terus bertambah. Solusi dari permasalahan tersebut adalah penggunaan IP versi 6 (IPv6) [3]. Protokol IPv6 adalah protokol pengalamatan yang digunakan dalam jaringan Intenet yang dikembangkan untuk memberikan solusi permasalahan berkurangnya jumlah alokasi alamat dari IPv4. Jumlah atau ukuran IPv6 lebih besar dibandingkan dengan IPv4 yaitu sebesar 128 bit. Hal ini akan mendukung tren jumlah pengguna Internet yang terus bertambah.

Perangkat router berfungsi menghubungkan perangkat dalam jaringan yang berbeda, sehingga perangkat tersebut dapat bertukar informasi dalam jaringan. Cara kerja perangkat router dalam menentukan jalur sebagai jalur pengiriman paket data dari perangkat sumber ke tujuan menggunakan tabel routing. Pencarian informasi rute dilakukan menggunakan acuan tabel routing. Informasi rute dikumpulan oleh router dengan mengaktifkan protokol routing. Proses routing dinamis terjadi dalam jaringan dengan memanfaatkan bantuan protokol routing [4]. Informasi rute akan didistribusikan ke router-router yang lain dalam jaringan 
oleh protokol routing tersebut. Informasi rute akan terbentuk, sehingga jalur dapat ditentukan ketika paket masuk ke perangkat router untuk diteruskan ke tujuan. Terdapat beberapa jenis routing dinamis diantaranya-nya OSPF (Open Shortest Path First) dan IS-IS (Intermediate System - Intermediate System) yang termasuk golongan protokol routing berbasis link-state.

Pada jaringan skala besar akan menggunakan lebih dari satu protokol routing. Dari beberapa pilihan protokol routing yang ada seperti RIP, OSPF, EIGRP, dan IS-IS akan digunakan dalam jaringan [5],[6]. Peningkatan jumlah perangkat yang terhubung ke jaringan Internet yang terus bertambah dari waktu ke waktu, mengakibatkan penipisnya alokasi alamat IPv4, sehingga peralihan atau transisi ke penggunaan alamat IPv6 harus diimplementasikan [7],[8]. Pada penelitian ini menerapkan konsep penggunan protokol routing OSPFv3 yang sudah mendukung implementasi jaringan dengan protokol IPv6 dan protokol routing IS-IS yang juga sudah mendukung IPv6. Kinerja proses redistribusi informasi rute yang dilakukan oleh router ABR (Autonomous Border Router) [9] akan diamati. Parameter pengujian menggunakan delay, throughput, packet loss, dan jitter.

\section{KaJian PUSTaKa}

Beberapa penelitian telah dilakukan untuk meneliti penggunaan teknologi redistribusi pada sebuah jaringan dengan protokol routing yang berbeda. Andry [9] melakukan penelitian mengenai konsep dan perancangan sebuah protokol routing EIGRP, RIPv2 dan OSPF melalui metode redistribusi. Metode redistribusi dipilih sebagai salah satu cara untuk menghubungkan beberapa jaringan dengan penggunaan protokol routing yang berbeda dengan menggunakan mekanisme pengalamatan IPv6. Metode pengujian menggunakan pengiriman paket ICMP dalam jaringan. Hasil dari pengujian diperoleh data bahwa nilai waktu pengiriman paket data ICMP paling cepat yaitu pada saat pengujian proses redistribusi dari EIGRP ke OSPF dengan nilai rata - rata 3.478 detik. Nilai waktu pengiriman paket data ICMP paling lama yaitu pada proses redistribusi dari OSPF ke EIGRP dengan nilai rata - rata 4.976 detik.

Fauzan [10] juga melakukan sebuah penelitian yang berkaitan dengan metode redistribusi. Metode penelitian yang digunakan yaitu dengan menggunakan topologi tipe hirarki yang terdiri dari beberapa tingkatan topologi jaringan. Penerapan beberapa jenis protokol routing juga diterapkan pada jaringan uji. Protokol routing yang digunakan diantaranya yaitu EIGRP, OSPF dan RIP. Pengujian dirancang dan dilakukan menggunakan software jaringan Cisco Packet Tracer. Berdasarkan hasil penelitian didapatkan hasil bahwa metode redistribusi tidak mengurangi waktu yang dibutuhkan dalam proses pengiriman data dari sumber hingga ke tujuan. Hasil pengukuran menunjukkan nilai throughput sebesar $0.99 \mathrm{Kbps}$ sampai dengan 1.6 Kbps dan nilai delay sebesar 76 ms sampai dengan 90 ms.

Performasi dari metode redistribusi sangat berpengaruh dalam sebuah jaringan. Hal ini diperkuat oleh penelitian yang dilakukan oleh Dadang [11]. Dengan menggunakan teknologi redistribusi pada protokol routing, maka akan terbentuk sebuah infrastruktur jaringan komputer yang dapat menggunakan beberapa protokol routing berbeda dalam jaringan komputer. Dengan adanya redistribusi, maka setiap paket yang sedang dipertukarkan pada masing-masing router akan berpengaruh pada pemakaian bandwidth saluran, pengiriman paket broadcast, dan tingkat stabilitas jaringan. Protokol routing yang digunakan pada penelitian ini menggunakan jenis routing pada kategori distance vector dan link state yaitu EIGRP, OSPF dan BGP.

\section{Metode Penelitian}

Penelitian penggunaan metode redistribusi antar protokol routing OSPFv3 dengan IS-IS yang sudah mendukung penggunan protokol IPv6 berbasiskan lab tidak mengimplementasikan perangkat asli. Perangkat lunak yang digunakan adalah GNS3 dalam membuat topologi jaringan dan Wireshark yang digunakan untuk mengambil dan menganalisa data. 


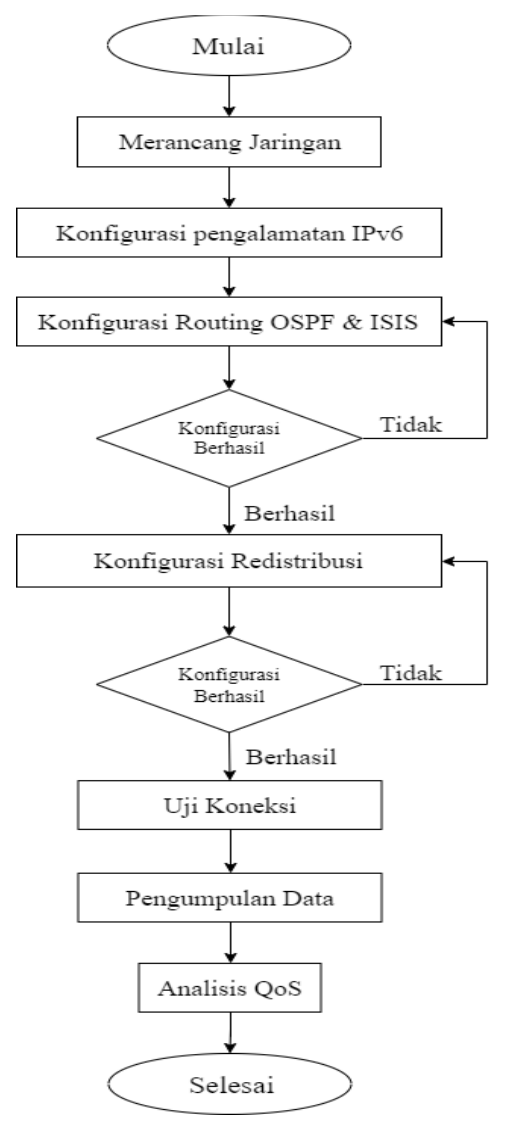

Gambar 1. Diagram Alur Penelitian

Gambar 1 menjelaskan tentang tahapan penelitian. Proses penelitian dimulai dari perencanaan jaringan yang digunakan untuk melakukan pengujian. Peran perangkat router sangat diperlukan dalam proses perencanaan jaringan. Pengujian menitikberartkan pada proses redistribusi antar protokol routing yang berbeda. Proses routing adalah proses dalam menentukan jalur terbaik menuju ke alamat network tujuan dan perangkat yang difungsikan untuk melakukan hal tersebut adalah router. Spesifikasi perangkat router yang digunakan adalah produk dari Cisco dengan seri router 7200 .

Sebelum data dapat dipertukarkan antar perangkat, mekanisme pengalamatan perlu dilakukan. Protokol pengalamatan menggunakan IP (Internet Protocol) versi 6. Mekanisme redistribusi yang digunakan dalam penelitian adalah dengan menggunakan konsep pengalamatan IPv6, dimana protokol routing yang digunakan adalah OSPFv3 dan IS-IS. Kedua protokol routing tersebut dapat dikonfigurasi apabila semua interface perangkat dalam jaringan sudah diberikan alamat IPv6. Tahapan proses konfigurasi mekanisme redistribusi akan dilakukan apabila proses routing dengan penggunaan masing-masing protokol routing sesuai dengan wilayah jaringan-nya berhasil dikonfigurasi dengan baik. Tahapan dari proses konfigurasi mekanisme redistribusi merupakan tahapan akhir sebelum melakukan proses pengambilan dan analisa data.

\section{A. Perancangan Jaringan}

Perancangan jaringan dilakukan untuk memberikan penjelasan dan gambaran dari proses simulasi. Perancangan jaringan meliputi proses pembuatan topologi untuk proses simulasi, pengalokasian alamat IP yang dibutuhkan untuk mengalamati interface perangkat dalam jaringan dan layanan yang akan digunakan untuk proses pembangkitan data. 


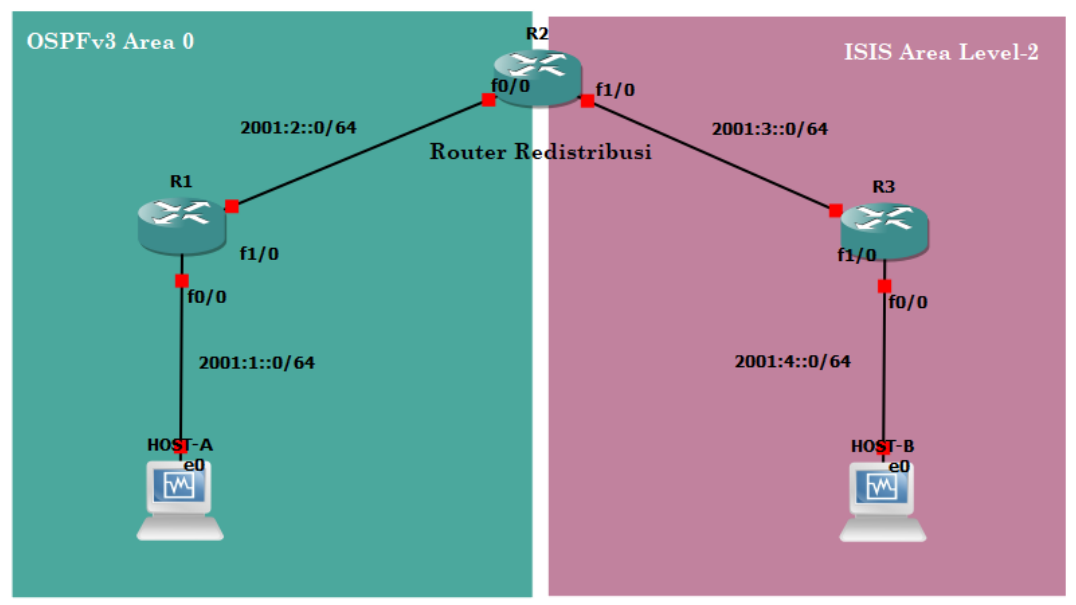

Gambar 2. Topologi jaringan uji

Topologi jaringan yang digunakan dalam proses pengujian mekanisme redistribusi adalah menggunakan tiga buah router dan dua buah komputer. Terdapat tiga buah router yang digunakan dalam proses pengujian mekanisme redistribusi pada jaringan IPv6 yaitu R1, R2, dan R3. Posisi router R3 adalah akan bertindak sebagai router ABR (Autonomous Border Router) seperti yang terlihat pada keterangan gambar 2. Peran dari router ABR memegang fungsi yang penting dalam jaringan yang melibatkan atau mengaktifkan protokol routing lebih dari satu buah. Pada dasarnya, paket hanya akan dipertukarkan pada wilayah jaringan dengan penggunaan protokol routing yang sama. Apabila ditemui jaringan dengan penggunaan lebih dari satu protokol routing, maka perlu peran dari router ABR yang akan meneruskan paket tersebut ke wilayah jaringan yang mengaktifkan protokol routing yang berbeda. Router R1 dan R2 terhubung pada jaringan yang mengaktifkan protokol routing OSPFv3, sedangkan protokol routing IS-IS diaktifkan pada router R2 dan R3. Pada router ABR (R2) akan diaktifkan dua protokol routing yang berbeda yaitu OSPFv3 dan ISIS. Proses redistribusi juga akan dilakukan pada router tersebut. Simulasi sesuai dengan keterangan gambar 2 menggunakan bantuan software GNS3 dan tipe dari perangkat router Cisco yang digunakan adalah seri 7200. Semua interface perangkat terhubung dan berkomunikasi dengan menggunakan pengalamatan IPv6. Tahapan awal sebelum dilakukan proses pengujian jaringan yaitu dengan memberikan alamat IP pada masing-masing interface perangkat.

Tabel 1. pengalamatan IP pada interface perangkat

\begin{tabular}{|c|c|c|}
\hline Perangkat & Interface & Alamat Ipv6 \\
\hline \multirow{2}{*}{ R1 } & $\mathrm{Fa} 0 / 0$ & $2001: 1:: 1 / 64$ \\
\cline { 2 - 3 } & $\mathrm{Fa} 1 / 0$ & $2001: 2:: 2 / 64$ \\
\hline \multirow{2}{*}{$\mathrm{R} 2$} & $\mathrm{Fa} 0 / 0$ & $2001: 2:: 1 / 64$ \\
\cline { 2 - 3 } & $\mathrm{Fa} 1 / 0$ & $2001: 3:: 1 / 64$ \\
\hline \multirow{2}{*}{$\mathrm{R} 3$} & $\mathrm{Fa} 1 / 0$ & $2001: 3:: 2 / 64$ \\
\cline { 2 - 3 } & $\mathrm{Fa} 0 / 0$ & $2001: 4:: 1 / 64$ \\
\hline \multirow{2}{*}{ Host A } & Ethernet & $2001: 1:: 10 / 64$ \\
\hline Host B & Ethernet & $2001: 4:: 10 / 64$ \\
\hline
\end{tabular}

Fungsi dari Host A dan Host B pada skenario perancangan topologi jaringan pada gambar 2 adalah untuk membangkitkan data. Aplikasi yang digunakan antara kedua komputer tersebut adalah layanan transfer file dengan ukuran file yang dipertukarkan dibuat bervariasi. Alamat network yang digunakan oleh host A adalah 2001:1::/64 dan host B adalah 2001:4::/64 seperti yang terlihat pada keterangan tabel 1. Host A 
terletak pada satu wilayah jaringan yang sama dengan router R1 pada interface Fa0/0. Sedangkan Host B terletak pada satu wilayah jaringan yang sama dengan router R3 pada interface Fa0/0. Terdapat empat buah wilayah jaringan yang digunakan dalam proses pengujian skenario redistribusi jaringan IPv6. Dua wilayah jaringan menggunakan mekanisme routing dinamis dengan mengaktifkan protokol routing OSPFv3 dan dua wilayah jaringan yang lain menggunakan protokol routing IS-IS.

\section{Hasil dan Pembahasan}

Pengujian tentang konsep redistribusi dengan menggunakan jaringan IPv6 melibatkan dua protokol routing yang berbeda yaitu OSPFv3 dan IS-IS dilakukan dengan menggunakan software GNS3. Layanan yang diaktifkan sebagai sarana untuk mengukur performansi jaringan yaitu proses transfer file dengan menggunakan bantuan protokol SMB (Server Message Block). Proses komunikasi dilakukan dengan menggunakan konsep client-server. Host B diposisikan sebagai komputer yang melakukan proses sharing file dengan ukuran bervariasi diantaranya; $5 \mathrm{MB}, 15 \mathrm{M}, 25 \mathrm{MB}$ dan $50 \mathrm{MB}$. Komputer yang akan melakukan proses unduh (download) file dari host B adalah host A. Sebelum dilakukan proses uji performansi dengan proses transfer file, kedua komputer dan interface perangkat router sudah dialokasikan alamat IPv6. Percobaan untuk menghasilkan data hasil percobaan dilakukan sebanyak tiga puluh kali. Parameter yang digunakan sebagai acuan dalam menilai performansi jaringan dari mekanisme redistribusi yang diaktifkan pada router R2 (ABR) diantaranya adalah delay, throughput dan packet loss. Sistem operasi yang digunakan pada kedua komputer adalah Windows 10.

\section{A. Pengujian Parameter Throughput}

Throughput merupakan bandwidth sesungguhnya yang digunakan pada layanan sharing file yang diukur dalam waktu dan jaringan tertentu [12]. Pengukuran throughput dilakukan pada sisi host A sebagai komputer yang melakukan proses unduh (download) file dari host B sebagai komputer server. Software wireshark digunakan untuk mengukur nilai throughput dan software tersebut diaktifkan pada sisi host A. Hasil dari pengukuran nilai throughput terlihat pada keterangan Gambar 3. Pengukuran nilai throughput dilakukan pada sisi dua arah yaitu pada arah host A menuju host B. Arah dari proses komunikasi ini adalah proses perjalanan data dari jaringan OSPFv3 menuju ke jaringan IS-IS. Pengukuran dilanjutkan dengan menilai nilai throughput dari arah kebalikannya yaitu dari jaringan IS-IS menuju ke OSPFv3. Proses komunikasi akan berawal dari host B yang bertindak sebagai client dan host A yang diposisikan sebagai server.

Grafik dari rata-rata throughput sesuai gambar 3 memberikan informasi tentang variasi perubahan nilai throughput yang mengalami kenaikan dengan ukuran data yang juga mengalami kenaikan. Hasil pengukuran memperlihatkan bahwa dengan semakin besar ukuran data yang dipertukarkan antara host A dengan host $\mathrm{B}$, nilai throughput yang dihasilkan juga semakin besar. Hasil pengukuran nilai throughput kemudian akan dicocokan dengan standarisasi dari TIPHON sesuai pada keterangan tabel 2.

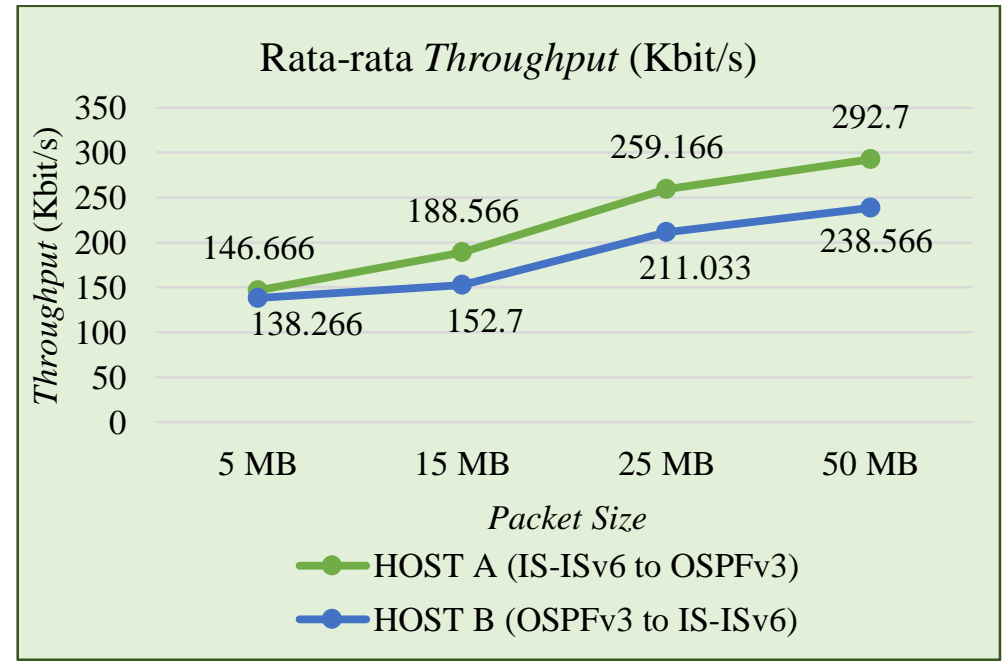

Gambar 3. Nilai throughput pada layanan sharing file 
Tabel 2. Standar TIPHON untuk parameter throughput [13]

\begin{tabular}{|c|c|}
\hline Klasifikasi standard & Throughput (\%) \\
\hline Sangat Bangus & 100 \\
\hline Bagus & 75 \\
\hline Sedang & 50 \\
\hline Buruk & $<25$ \\
\hline
\end{tabular}

Besaran nilai throughput terbesar terjadi ketika ukuran data yang dipertukarkan antara host A dan host B $50 \mathrm{MB}$. Pada ukuran file yang dipertukarkan sama yaitu $50 \mathrm{MB}$, perjalanan paket dari jaringan IS-IS menuju ke jaringan OSPF menghasilkan performansi yang lebih baik. Pada perjalanan paket dari jaringan IS-IS menuju ke jaringan OSPF, pengukuran dilakukan pada host A. Nilai throughput yang dihasilkan pada sisi host A yaitu sebesar 292,7 Kbps. Dari hasil pengukuran juga memperlihatkan terjadi perbedaan hasil pengukuran nilai throughput jika arah perjalanan paket diubah yaitu dari jaringan OSPF menuju ke jaringan IS-IS. Pengukuran dari arah ini menggunakan host B sebagai acuan. Software wireshark sebagai software untuk mengukur nilai throughput diaktifkan pada host B. Hasil pengukuran nilai throughput dari host B memperlihatkan bahwa terjadi penurunan nilai throughput yaitu sebesar 238,566 Kbps. Berdasarkan acuan tabel standarisasi Tiphon, kedua hasil nilai throughput dari arah yang berbeda masih dalam kategori sangat bagus. Hasil pengukuran memperlihatkan bahwa arah komunikasi dari jaringan IS-IS menuju ke jaringan OSPF menghasilkan nilai yang lebih baik. Proses redistribusi akan lebih baik jika arah paket berasal dari jaringan IS-IS. Hal ini memperlihatkan bahwa proses enkapsulasi yang dilakukan oleh protokol routing ISIS lebih sederhana dibandingkan dengan OSPF.

\section{B. Pengujian Parameter Packet Loss}

Packet loss merupakan paket yang gagal dikirimkan selama dalam perjalanan menuju ke perangkat tujuan [14]. Nilai dari packet loss ini merupakan nilai perbandingan antara jumlah paket yang gagal dikirimkan dengan jumlah total dari paket yang dikirimkan. Sebuah sistem jaringan dikatakan memiliki performansi yang baik apabila parameter packet loss mendekati $0 \%$. Artinya tidak ada paket yang hilang selama dalam proses pengiriman paket. Perhitungan packet loss dalam proses pengujian jaringan menggunakan acuan dari standarisasi yang dikeluarkan oleh TIPHON sesuai dengan keterangan pada tabel 3.

Hasil pengujian parameter delay untuk proses redistribusi antara protokol routing OSPFv3 dan IS-IS terdapat pada keterangan gambar 4. Hasil pengujian menunjukkan nilai rata-rata dari parameter packet loss mendekati $0 \%$ baik dari host-A maupun host-B. Proses pengujian juga dilakukan dari dua arah sumber yaitu host A maupun host $\mathrm{B}$. Pengujian yang dimulai dari host A berarti arah komunikasi berawal dari host A mengirimkan data menuju ke host B. Host A yang berasal dari jaringan OSPFv3 mengirimkan data menuju ke host B yang berasal dari jaringan IS-IS. Pada ukuran data yang dipertukarkan sebesar $50 \mathrm{MB}$, arah pengiriman data dari host A memberikan nilai packet loss yang lebih kecil dibandingkan data yang berasal dari host B.

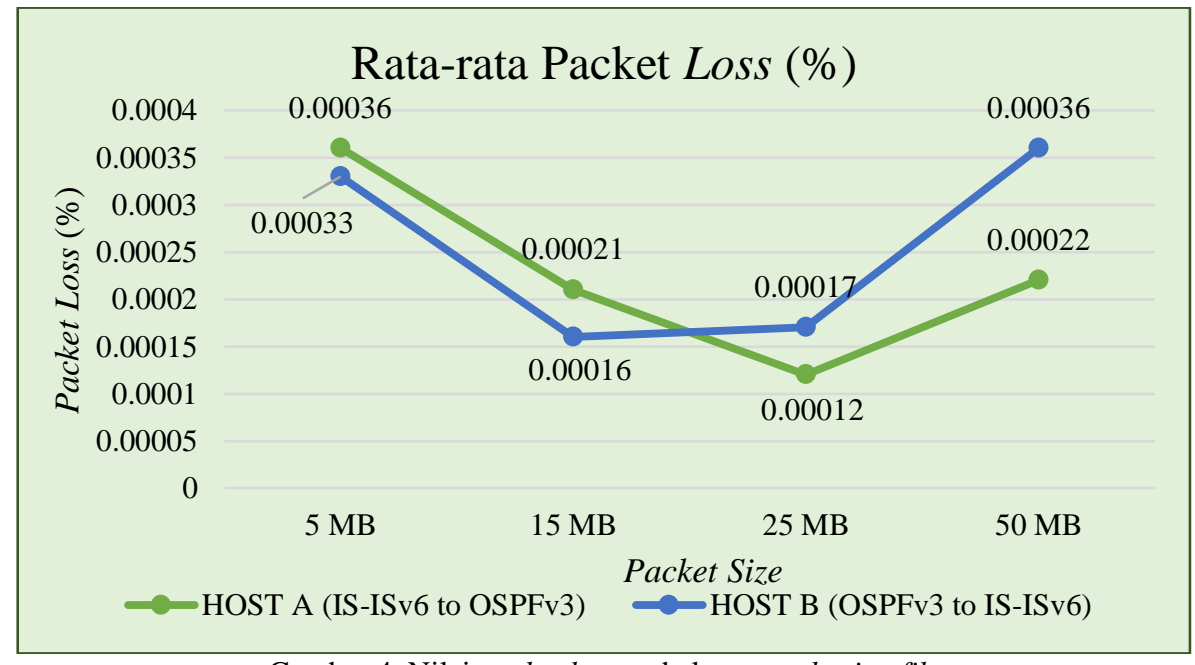

Gambar 4. Nilai packet loss pada layanan sharing file 
Tabel 3. Standar TIPHON untuk parameter packet loss [13]

\begin{tabular}{|c|c|}
\hline Klasifikasi standard & Packet Loss (\%) \\
\hline Sangat Bangus & $0 \%$ \\
\hline Bagus & $3 \%$ \\
\hline Sedang & $15 \%$ \\
\hline Buruk & $25 \%$ \\
\hline
\end{tabular}

Nilai packet loss yang dihasilkan ketika data dikirimkan dari host B adalah sebesar 0,0036\%. Nilai yang lebih kecil dihasilkan ketika data berasal dari wilayah jaringan IS-IS yaitu dari host A. Nilai packet loss yang dihasilkan dari host A bernilai 0,00022\%. Dari hasil pengujian memperlihatkan bahwa proses redistribusi dari data yang berasal wilayah jaringan IS-IS lebih baik dibandingkan dengan OSPFv3. Proses enkapsulasi dari protokol routing IS-IS lebih baik dibandingkan dengan OSPFv3. Hasil pengujian dari kedua wilayah jaringan yang berbeda masih dikategorikan sangat bagus jika menggunakan acuan dari TIPHON.

\section{Pengujian Parameter Delay}

Delay merupakan lamanya waktu yang diperlukan dari proses pengiriman data antara perangkat pengirim dan penerima paket. Semakin lama proses pengiriman data dari perangkat sumber akan menunjukkan bahwa performansi jaringan buruk. Kriteria jaringan baik, salah satu parameter yang digunakan adalah dengan menggunakan acuan dari waktu pengiriman data yang sangat singkat. Parameter delay dari proses pengujian menggunakan acuan dari Tiphon sesuai dengan keterangan pada tabel 4.

Tabel 4. Standar TIPHON untuk parameter delay [13]

\begin{tabular}{|c|c|}
\hline Klasifikasi standard & Delay $(\mathrm{ms})$ \\
\hline Sangat Bagus & $<150 \mathrm{~ms}$ \\
\hline Bagus & 150 s.d. $300 \mathrm{~ms}$ \\
\hline Sedang & 300 s.d. $450 \mathrm{~ms}$ \\
\hline Buruk & $>450 \mathrm{~ms}$ \\
\hline
\end{tabular}

Tiphon memberikan standarisasi nilai dari waktu data dikirimkan ke perangkat tujuan dengan empat parameter nilai; sangat bagus, bagus, sedang, dan buruk. Jaringan tidak layak untuk digunakan untuk penggunan umum jika menghasilkan parameter delay dengan kriteria buruk. Hasil kriteria ini sangat dihindari dari hasil proses pembangunan jaringan. Hasil kriteria yang sangat diharapkan dari sebuah jaringan adalah ketika jaringan tersebut mempunyai performansi yang sangat baik. Menurut standarisasi yang diberikan oleh Tiphon yaitu sebuah jaringan dikatakan sangat baik apabila dapat memberikan nilai delay kurang dari 150 ms. Pengukuran hasil pengujian menggunakan target nilai kurang dari 150 ms. Hasil pengukuran nilai delay dari pengetesan jaringan dengan mekanisme redistribusi pada router R2 terdapat pada keterangan gambar 5 .

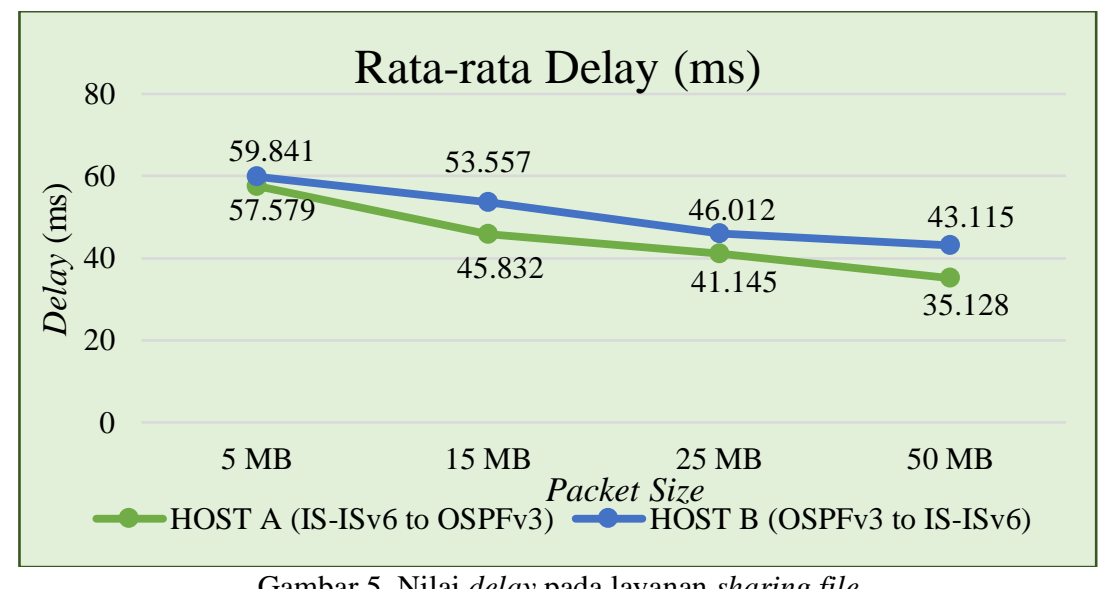

Gambar 5. Nilai delay pada layanan sharing file 
Perhitungan nilai delay masih menggunakan software wireshark. File hasil pengukuran menggunakan software wireshark adalah ber-ekstensi *csv. Proses konversi diperlukan dari file *csv supaya bisa dibaca oleh software Ms.Excel. Hasil pengukuran memperlihatkan proses pengiriman data yang berasal dari jaringan IS-IS memberikan nilai yang lebih baik dibandingkan dengan data dikirimkan dari jaringan OSPFv3. Hasil pengukuran pada jaringan yang menerapkan proses redistribusi masih memberikan nilai yang lebih baik jika data tersebut berasal dari jaringan IS-IS. Nilai delay yang dihasilkan ketika data tersebut dikirimkan dari wilayah jaringan IS-IS yaitu dari host A menghasilkan nilai sebesar 35,128 ms. Hasil pengukuran ini masih menggunakan ukuran data yang dikirimkan sebesar $50 \mathrm{MB}$. Perbedaan hasil tersebut ketika data tersebut dikirimkan dari jaringan OSPFv3 yaitu data dikirimkan dari host $\mathrm{B}$. Hasil nilai delay dari data yang dikirimkan dari host $\mathrm{B}$ menuju ke host A yang berada pada jaringan OSPFv3 adalah sebesar $43,115 \mathrm{~ms}$.

\section{KESIMPULAN}

Hasil pengujian proses redistribusi dengan menggunakan dua protokol routing yang berbeda yaitu OSPFv3 dan IS-IS yang sudah mendukung protokol IPv6 memperlihatkan bahwa proses redistribusi yang berasal dari jarigan IS-IS menuju jaringan OSPFv3 memberikan hasil yang lebih baik dilihat dari parameter throughput, packet loss, dan delay. Hasil pengujian memperlihatkan jaringan yang mengaktifkan protokol routing IS-IS memberikan performansi yang lebih baik dibandingkan dengan OSPFv3. Proses enkapsulasi lebih sederhana yang digunakan oleh protokol routing IS-IS dibandingkan dengan OSPFv3 menjadikan salah satu alasan protokol routing tersebut memberikan performansi yang lebih baik.

\section{REFERENSI}

[1] N. F. Rahmah, “Analisis Perbandingan Routing Protokol OSPFv3 dengan RIPng Pada Jaringan IPv6” Univ. Nusant. PGRI Kediri, vol. 01, no. April, pp. 1-7, 2017.

[2] S. R. Javid and S. K. Dubey, "Implementing OSPFv3 in IPv6 network," Proc. 2016 6th Int. Conf. - Cloud Syst. Big Data Eng. Conflu. 2016, pp. 580-584, 2016.

[3] C. Russell, R. Deboer, C. Richmond, and J. Orcutt, "Development of IPv6."

[4] S. Budiyanto, "Protocol Routing," Vmware, vol. 5, no. 1, pp. 18-32, 2014.

[5] I. D. G. Widyakusuma, I. D. Irawati, and T. A. Wibowo, "Implementasi Algoritma Rsa Pada Interkoneksi Jaringan Ipv6 Dan Ipv4 Dengan Mekanisme Tunneling Mode 6To4," vol. 16, no. 2, pp. 114-122, 2013.

[6] R. John and S. Ying, "A Comparison of OSPFv3 and EIGRPv6 in a Small IPv6 Enterprise Network," Int. J. Adv. Comput. Sci. Appl., vol. 6, no. 1, pp. 162-167, 2015.

[7] M. A. Hossain and M. S. Akter, "Study and Optimized Simulation of OSPFv3 Routing Protocol in IPv6 Network," Glob. J. Comput. Sci. Technol., vol. 19, no. May, pp. 11-16, 2019.

[8] P. Hasan and P. wahyu purnawan, "Kajian Perbandingan Performansi Routing Protocol Ripng ," vol. 7, no. 1, pp. 1-90, 2018.

[9] A.- Maulana, "Penerapan Routing EIGRP, RIPv2 Dan OSPF Pada IPv6 Menggunakan Metode Redistribution," J. Pendidik. Teknol. dan Kejuru., vol. 15, no. 2, pp. 234-243, 2018.

[10] R. T. Jurnal, “Analisis Kinerja Routing Protokol RIPng Dengan OSPFv3 Pada Jaringan IPV6 Tunneling,” Petir, vol. 10, no. 2, pp. 56-36, 2018.

[11] S. Salam Samaan, "Performance Evaluation of RIPng, EIGRPv6 and OSPFv3 for Real Time Applications," J. Eng., vol. 24, no. 1, pp. 111-122, 2018.

[12] B. A. Forouzan, Data Communications and Networking (Fourth Edition). United States: Mc Graw Hill, 2007.

[13] ETSI, "Telecommunications and Internet Protocol Harmonization Over Networks (TIPHON," France, 1999.

[14] K. Nugroho, IP Routing Menggunakan Cisco \& Mikrotik Dalam Teori \& Praktik. Bandung: INFORMATIKA, 2016. 